\title{
YIELD AND QUALITY OF CHERRY TOMATO FRUITS IN HYDROPONIC CULTIVATION
}

\author{
PRODUÇÃO E QUALIDADE DE FRUTOS DE TOMATE CEREJA EM CULTIVO \\ HIDROPONIA
}

\author{
Nildo da Silva DIAS'; Adriana Araújo DINIZ²; Patrícia Ligia Dantas de MORAIS'; \\ Gledyson Dos Santos PEREIRA ${ }^{1}$; Francisco Vanies da Silva SÁ ${ }^{\mathbf{1}}$; \\ Bruno Goulart de Azevedo SOUZA ${ }^{1}$; Lourival Ferreira CAVALCANTE; \\ Miguel FERREIRA NETO ${ }^{1}$ \\ 1. Centro de Ciências Agrárias, Universidade Federal Rural do Semi-Árido - UFERSA, Mossoró-RN, Brasil. \\ vanies_agronomia@ hotmail.com; 2. Centro de Estudos Superiores de Balsas, Universidade Estadual do Maranhão - UEMA, Balsas, \\ MA, Brasil; 3. Centro de Ciências Agrárias, Universidade Federal da Paraíba - UFPB, Areia, PB, Brasil.
}

\begin{abstract}
Because of the food and industrial importance of tomato, it holds great significance, and is one of the most produced species using the hydroponic cultivation systems. The objective of this study was to evaluate the effects of different concentrations of nutrient solution on the production and quality of cherry tomatoes (Lycopersicon esculentum 'Samambaia') grown in a hydroponic system in protected conditions. The experiment was conducted in pots filled with coconut fiber substrate using a randomized complete block design with four replications and six plants per plot. Five concentrations of nutrients were evaluated $(50,75,100,125$, and $150 \%$ of the standard nutrient solution); the solutions produced the following electrical conductivities: 1.8, 2.0, 2.6, 3.4, and $3.9 \mathrm{dS} \mathrm{m}^{-1}$, respectively. At 90 days after transplanting, the tomato fruits were harvested, at which time the production variables and post-harvest quality of mature fruits were determined. The best production and post-harvest quality indexes of cherry tomatoes ('Samambaia') were found when using $111 \%$ of the standard nutrient solution, corresponding to the concentrations of 9.44, 2.44, 2.22, 6.44, 4.11, 2.44, and 2.78 $\mathrm{mmol}_{\mathrm{c}} \mathrm{L}^{-1}$, of $\mathrm{NO}_{3}{ }^{-}, \mathrm{NH}_{4}{ }^{+}, \mathrm{P}, \mathrm{K}, \mathrm{Ca}, \mathrm{Mg}$, and $\mathrm{S}$, respectively; and 66.6, 55.5, 14.4, 1.89, 0.56, and 0.44 mmol $_{\mathrm{c}}$ $\mathrm{L}^{-1}$, of $\mathrm{Fe}, \mathrm{B}, \mathrm{Mn}, \mathrm{Zn}, \mathrm{Cu}$, and $\mathrm{Mo}$, respectively. Nutrient solutions with electrical conductivity above $2.89 \mathrm{dS}$ $\mathrm{m}^{-1}$ severely reduced the fruit yield of cherry tomatoes.
\end{abstract}

KEYWORDS: Lycopersicon esculentum. Nutrients. Irrigation. Hydroponics system.

\section{INTRODUCTION}

The growing demand for increased productivity and quality of agricultural products is a catalyst for agricultural development, thus, there is a constant need to adapt products and the means of production. This aspect is particularly relevant to horticulture because most producers have a small growing area in which they seek to obtain the maximum possible income (RINALDI et al., 2008). Soilless crops allow production in a small area and can maintain product quality at satisfactory levels, as well as serving as a strategy for soil conservation and preservation of water sources (OLIVEIRA et al., 2014, OLIVEIRA et al., 2016).

Several authors have verified that plants respond differently to the same salinity conditions of nutrient solution when cultivated in soil and hydroponics. In soil cultivation, the moisture level varies between irrigations, decreasing the osmotic and matric potentials. However, in hydroponic cultivation, the potassium potential is practically null due to the saturated state in which the plant is growing. This is an advantage when only saline waters are available to prepare the nutrient solutions. Therefore, with similar salinity conditions, hydroponic cultivation allows a greater absorption of water and nutrients by the plants, with a lower energy expenditure in comparison to soil cultivation (SILVA et al., 2013a; SÁ et al., 2015; SANTOS et al., 2017).

Furthermore, hydroponic crops make it possible to obtain better quality products when compared to conventional systems. Indoor hydroponic crops offer greater uniformity of crop/fruit, better water use efficiency, as well as the ability to control other factors during production (GENÚNCIO et al., 2006; CARDOSO et al., 2017; SANTOS et al., 2017).

The formulations of the nutrient solutions used in the hydroponic production of plants are of great interest. Several formulations of nutrient solution are proposed in the specialized literature, however, it is necessary to determine the effects of solution concentration and nutrient ratios on plant growth, plant development, production, and fruit 
quality (FERNANDES; MARTINEZ; OLIVEIRA, 2002; MELO et al., 2014; DINIZ et al., 2015).

In Brazil there has been significant growth in the tomato growing sector, with a particular focus on hybrid varieties, especially those within the cherry tomato group (GUILHERME et al., 2014). This demand has partly been driven by the market, as the use of cherry tomatoes as adornments and appetizers in the cooking has become more popular. Besides the values of market, has been more interested farmers because they spread their cultivation in a protected environment (CARVALHO; TESSARIOLI NETO, 2005).

Vegetables respond very well to hydroponic cultivation and most of the water sources of the Brazilian semi-arid region are saline. The objective of this study was to evaluate the effects of the application of different concentrations of nutrient solution on the production and quality of cherry tomato fruits cultivated in a hydroponic system in protected environment conditions.

\section{MATERIAL AND METHODS}

The experiment was carried out in a chapeltype greenhouse with a ceiling height of $3.0 \mathrm{~m}, 20 \mathrm{~m}$ length, and $14 \mathrm{~m}$ width, located in the Department of Environmental Sciences of the Federal Rural Semi-Arid University (UFERSA), Mossoró, State of Rio Grande do Norte, Brazil ( $5^{\circ} 11^{\prime} 31^{\prime \prime}$ S, $37^{\circ} 20^{\prime} 40^{\prime \prime}$ $\mathrm{W})$. The average altitude of the site is $18 \mathrm{~m}$. According to Köppen's climatic classification, the climate of the region is BSwh,' with an average annual temperature of $27.3^{\circ} \mathrm{C}$, fairly irregular rainfall with an annual average of $672.9 \mathrm{~mm}$, and a relative humidity of $68.9 \%$.

A randomized block design, with four replications, and six plants per plot, was used as the experimental design. The effects of five nutrient solution concentrations were evaluated: $\mathrm{T}_{1}=50, \mathrm{~T}_{2}$ $=75, \mathrm{~T}_{3}=100, \mathrm{~T}_{4}=125$, and $\mathrm{T}_{5}=150 \%$ of the standard nutrient solution recommended by Furlani et al. (1999) for tomato culture under tropical conditions.

The composition of the macronutrients in the solutions were: $\mathrm{T} 1=4.25,1.1,1.0,2.9,1.85,1.1$ and $1.25 ; \mathrm{T} 2=6.375,1.65,1.5,4.35,2.775,1.65$ and 1.875; T3 = 8.5, 2.2, 2.0, 5.8, 3.7, 2.2 and 2.5; $\mathrm{T} 4=10.625,2.75,2.5,7.25,4.625,2.75$ and 3.125 ; $\mathrm{T} 5=12.75,3.3,3.0 ; 8.7,5.55,3.3$ and 3.75 mmol $_{\mathrm{c}}$ $\mathrm{L}^{-1}$, of $\mathrm{NO}_{3}^{-}, \mathrm{NH}_{4}^{+}, \mathrm{P}, \mathrm{K}, \mathrm{Ca}, \mathrm{Mg}$ and $\mathrm{S}$, respectively, according to the recommendation for tomato, cited by Furlani et al. (1999). To prepare the nutrient solution, calcium nitrate, potassium nitrate, monoammonium phosphate (MAP), and magnesium sulphate were added to $250 \mathrm{~L}$ of tap water $(\mathrm{EC}=0,6$ $\mathrm{dS} \mathrm{m}{ }^{-1}$ ) in the following amounts respectively: $\mathrm{T}_{1}$ (95.62, 88.35, 36.9, $53.75 \mathrm{~g}) ; \mathrm{T}_{2}(143.44,132.52$, $55.35,80.62 \mathrm{~g}) ; \mathrm{T}_{3}(191.25,176.70,73.80,107.5 \mathrm{~g})$; $\mathrm{T}_{4}(239.06,220.87,92.25,134.37 \mathrm{~g}) ;$ and $\mathrm{T}_{5}$ (286.87, 265.05, 110.7, 161.25 g).

The composition of the micronutrients in all solutions was $60,50,13,1.7,0.5$, and $0.4 \mathrm{mmol}_{\mathrm{c}} \mathrm{L}^{-1}$, of $\mathrm{Fe}, \mathrm{B}, \mathrm{Mn}, \mathrm{Zn}, \mathrm{Cu}$ and $\mathrm{Mo}$, respectively, according to the recommendation for tomato, cited by Furlani et al. (1999). Also, the following micronutrients were added (M): $4.41 \mathrm{~g}$ of $\mathrm{B}-\mathrm{H}_{3} \mathrm{BO}_{3}$, $0.58 \mathrm{~g}$ of $\mathrm{Cu}-\mathrm{CuSO}_{4}, 3.13 \mathrm{~g}$ of $\mathrm{Mn}-\mathrm{MnSO}_{4}$, and 0.37 $\mathrm{g}$ of $\mathrm{Mo}-\mathrm{Na}_{2} \cdot \mathrm{MoO}_{4} \cdot 2 \mathrm{H}_{2} \mathrm{O}$ and, as source of iron (I) $33.85 \mathrm{~g}$ of $\mathrm{Fe} 7$ was added. The combinations of $\mathrm{M}$ and I used in the nutritive solutions were as follows $\mathrm{T}_{1}: 50 \mathrm{~mL}$ of $\mathrm{M}$ and $50 \mathrm{~mL}$ of I; $\mathrm{T}_{2}: 75 \mathrm{~mL}$ of $\mathrm{M}$ and $75 \mathrm{~mL}$ of $\mathrm{I} ; \mathrm{T}_{3}: 100 \mathrm{~mL}$ of $\mathrm{M}$ and $100 \mathrm{~mL}$ of $\mathrm{I} ; \mathrm{T}_{4}$ : $125 \mathrm{~mL}$ of $\mathrm{M}$ and $125 \mathrm{~mL}$ of $\mathrm{I}$ and $\mathrm{T}_{5}: 150 \mathrm{~mL}$ of $\mathrm{M}$ and $150 \mathrm{~mL}$ of $\mathrm{I}$.

The physicochemical composition of the tap water used in the preparation of the nutrient solution was as follows: $\mathrm{EC}=0.60 \mathrm{dS} \mathrm{m}{ }^{-1} ; \mathrm{pH}=8.0 ; \mathrm{Ca}^{2+}=$ $0.6\left(\mathrm{mmol}_{\mathrm{c}} \mathrm{L}^{-1}\right) ; \mathrm{Mg}^{2+}=0.1\left(\operatorname{mmol}_{\mathrm{c}} \mathrm{L}^{-1}\right) ; \mathrm{Na}^{2+}=5.1$ $\left(\operatorname{mmol}_{\mathrm{c}} \mathrm{L}^{-1}\right) ; \mathrm{Cl}^{-}=1.8\left(\mathrm{mmol}_{\mathrm{c}} \mathrm{L}^{-1}\right) ; \mathrm{CO}_{3}{ }^{2}=0.5$ $\left(\mathrm{mmol}_{\mathrm{c}} \mathrm{L}^{-1}\right) ; \mathrm{HCO}_{3}^{-}=3.8\left(\mathrm{mmol}_{\mathrm{c}} \mathrm{L}^{-1}\right)$; and RAS $=$ $8.62\left(\mathrm{mmol} \mathrm{L}^{-1}\right)^{0,5}$. After the addition of the nutrients to the tap water, nutritive solutions were produced with electrical conductivities $(\mathrm{EC})$ of $\mathrm{T}_{1}=1.8, \mathrm{~T}_{2}=$ $2.0, \mathrm{~T}_{3}=2.6, \mathrm{~T}_{4}=3.4$, and $\mathrm{T}_{5}=3.9 \mathrm{dS} \mathrm{m} \mathrm{m}^{-1}$, respectively. To correct the $\mathrm{pH}$ of the solutions to values around 6.5 , sulfuric acid was added to the nutrient solution.

Each experimental plot was composed of an individual hydroponic system, consisting of 6 plastic pots of $11 \mathrm{~L}$, with spaces of $0.5 \mathrm{~m}$ between pots and $1.0 \mathrm{~m}$ between lines. The pots had holes drilled in their bases to drain excess water. The pots were filled with coconut fiber and placed on a support $0.10 \mathrm{~m}$ from the soil level of the greenhouse to avoid direct contact of the pot with the floor and to facilitate drainage. The plants were vertically tutured with the aid of string, and the other cultural treatments were carried out following the recommendations of Filgueira (2008).

A localized irrigation system with microtube emitters of $1.5 \mathrm{~mm}$ internal diameter was adopted. The nutrient solution was supplied through individual reservoirs with a capacity of $300 \mathrm{~L}$ each, suspended on a fixed iron structure at a height of 1.2 $\mathrm{m}$. The volume applied in each irrigation was determined according to plant water needs based on the water balance in the root zone. This was obtained from the difference between the applied volume and the volume drained in the previous 
irrigation, in extra pots arranged in the experimental area, to avoid losses of nutrients by leaching.

The cherry tomato seedlings ('Samambaia') were produced in trays of 180 cells with 1 tomato seed per cell, and irrigated twice a day with tap

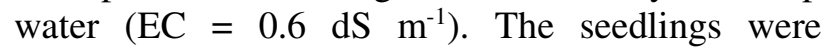
transplanted to the experimental units after 23 days. The tomato plants 'Samambaia' of determined growth habit. The plants were conducted with only one stem. The reproductive phase was started at 45 days, all the mature fruits were harvested between 70 and 90 days after transplanting to evaluate the yield, being determined the variables total production per plant, number and mean mass of the fruits. Samples of fruits with similar characteristics were taken to the Post-Harvest Laboratory of the Federal Rural Semi-Arid University (UFERSA) for analysis of total titratable acidity, total soluble solids, hydrogenation potential, and vitamin $\mathrm{C}$ content.

The titratable acidity was determined by titration using an aliquot of $1.0 \mathrm{~mL}$ of extracted, to which $49.0 \mathrm{~mL}$ of distilled water and 3 drops of $1 \%$ alcoholic phenolphthalein were added, using sodium hydroxide solution $(\mathrm{NaOH}) 0.1 \mathrm{~N}$, standardized with potassium biphthalate, as titrant (IAL, 2008). The soluble solids were determined directly in the homogenized juice using a digital refractometer (model PR - 100, Palette, AtagoCo LTD., Japan), according to the recommendation proposed by the Association of Official Analytical Chemists (AOAC, 2002). The hydrogenation potential $(\mathrm{pH})$ was determined using a $\mathrm{pH}$ meter (Model mPA 210P / Version 7.1, Tecnopon, Brazil), with direct insertion of the electrode, according to IAL (2008). Following the methods of AOAC (2002), the vitamin $\mathrm{C}$ content was determined by titration with 2,6-dichlorophenolindophenol (DFI) until a permanent clear rose coloration was obtained, using $1.0 \mathrm{~mL}$ of the diluted juice in $49.0 \mathrm{~mL}$ of oxalic acid $0.5 \%$.

Data were submitted to analysis of variance, the means of the results were compared by the F test (5\%) and submitted to polynomial regression analysis, with the software SISVAR 5.3 (FERREIRA, 2014).

\section{RESULTS AND DISCUSSION}

The proportion of nutrients in the nutrient solution (NS) influenced the production of fruits per cherry tomato plant in a quadratic form, with an estimated maximum production of $258.48 \mathrm{~g}$ in the nutrient solution concentration of $101.88 \%$; above this concentration there is a decrease in production
(Figure 1A). In general, the yield values of tomato varied from 127.62 to $283.62 \mathrm{~g}$ in function of the concentrations in the nutrient solution $(50,75,100$, 125 and $150 \%$ ). It can be inferred that fruit yield was negatively affected by the salinity of the hydroponic nutrient solution above $2.6 \mathrm{dS} \mathrm{m}^{-1}$, this was probably because of the deleterious effects of salinity caused by excess nutrients in solution.

The mean yield of fruits per plant found were higher than those reported by Silva et al. (2012) in experiments conducted in the open field and when irrigated with different salinity levels of irrigation water $\left(0.8,1.6,2.4,3.2\right.$, and $\left.4.0 \mathrm{dS} \mathrm{m}{ }^{-1}\right)$, which recorded average fruit weight of 70.30 , $101.54,101.63,123.50$, and $155.79 \mathrm{~g}$, respectively. On the other hand, Gomes et al. (2011) observed a linear reduction in the production of cherry tomato fruits in a hydroponic system using desalination. Furthermore, Medeiros et al. (2011) reported that salinity reduced the availability of water and nutrients to the plants, causing losses of average fruit weight as the saline concentration increased. Cosme et al. (2011) working with nutritional solution prepared with the addition of reject saline observed a reduction in the production of tomato fruits. The authors attributed this reduction to the increased salinity of the nutrient solution.

The increase of nutrient ratios in the nutrient solution significantly influenced the number of tomato fruits plant ${ }^{-1}(\mathrm{p}<0.01)$. The number of fruits ranged from 45.5 to 55.25 fruits per plant, and increased with increasing nutrient solution concentration (Figure 1B), with a maximum number of fruits of 54.01 in $116.19 \%$ concentration of standard nutritional solution. These values were higher than those obtained by Silva et al. (2012) in cherry tomato which were from 4.87 to 8.75 fruits per plant at saline concentrations of 0.8 to $4.0 \mathrm{dS} \mathrm{m}-$ 1 . These results may be associated with the plant response to nutrient solution concentrations, in other words, the high saline concentration of the nutrient solution causes a reduction in water absorption due to the osmotic effect and may also interfere with the availability of other nutrients and, consequently, causes reduction in the growth and the development of the plants (ROCHA et al., 2010; STRASSBURGER et al., 2011; CARDOSO et al., 2017; SANTOS et al., 2017).

The mean mass of cherry tomato fruit was linearly reduced by increasing the nutrient concentration in the nutrient solution by $0.66 \mathrm{~g}$ for a $25 \%$ increase in nutrient concentration (Figure 1C). Initially the reduction of the average mass of fruits was due to the increase in the number of fruits per plant. The plants grown with nutrient solution 
concentrations of 75 and $100 \%$ had double the number of fruits compared to the plants grown with $50 \%$ (Figure 1B). Plantas cultivadas em 125 e $150 \%$ de solução nutritiva tiveram menos frutos do que as plantas cultivadas com $100 \%$ de solução, e seus frutos pesaram menos em média. Isso pode estar diretamente relacionado aos efeitos de salinidade da solução nutritiva (Figura 1C). Cosme et al. (2011) studied the effects of salinity of nutrient solution on
DIAS, N. S. et al.

tomato plants, and verified that the growth and fruit production variables reduced significantly at high salinity levels. Other studies on the effects of salinity on plants have shown morphological alterations of the plants are common, resulting in reductions in growth, and changes to physiology and plant production (ROCHA et al., 2010; STRASSBURGER et al., 2011; SILVA et al., 2013a; DINIZ et al., 2015; SÁ et al., 2015).
A

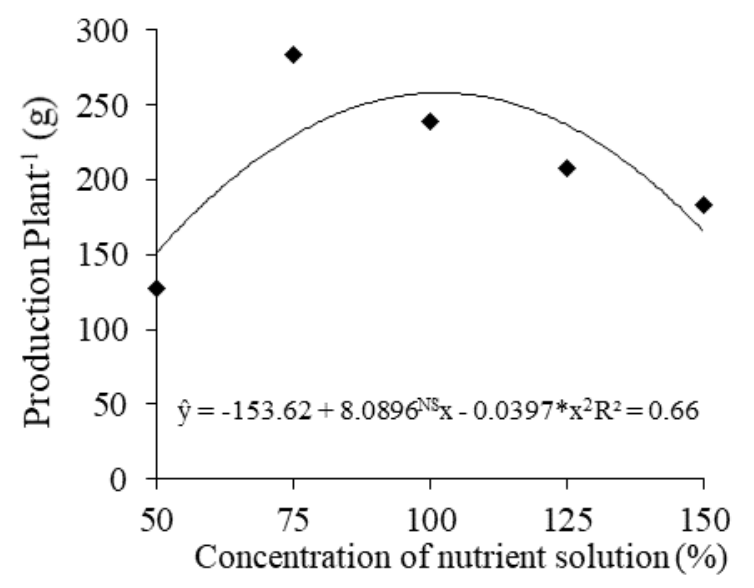

B

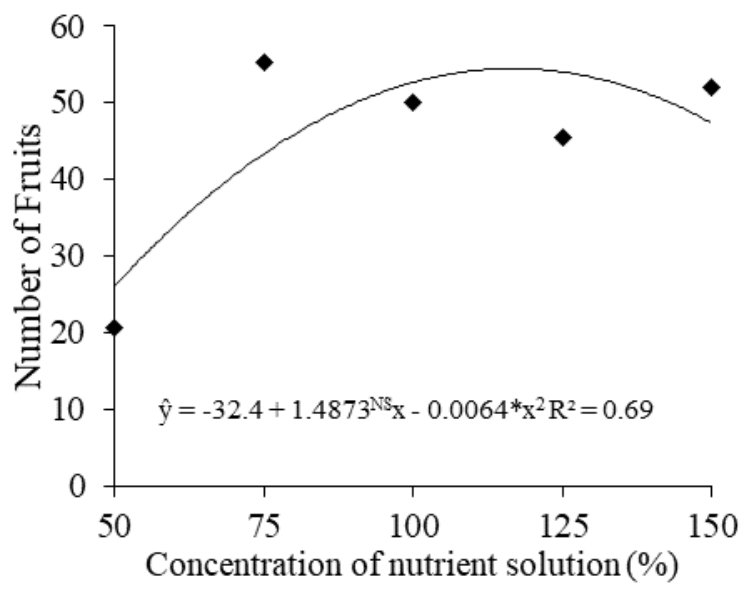

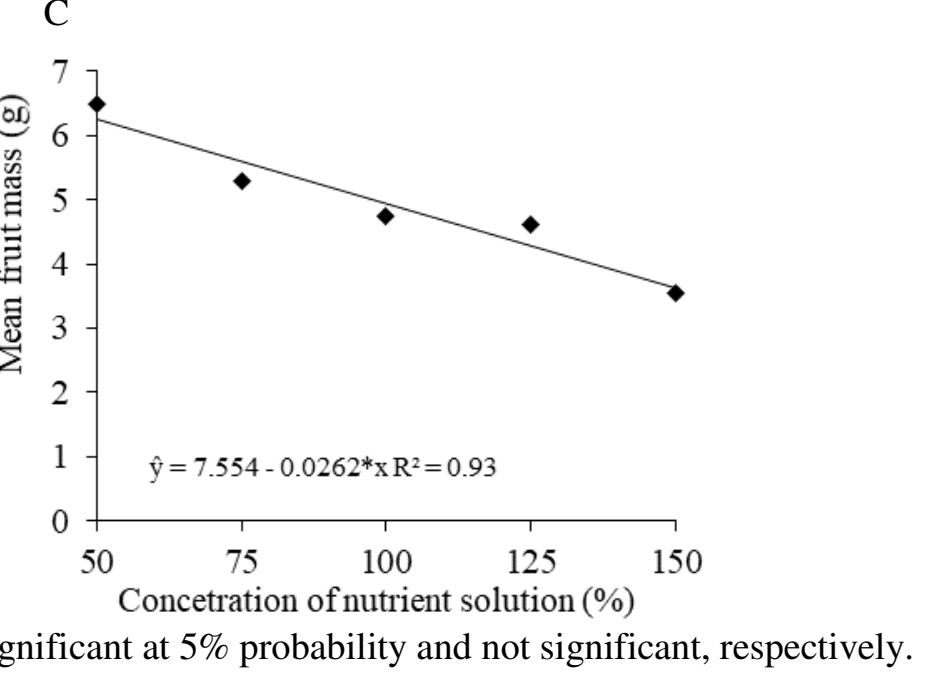

Figure 1. Production (A), number of fruits (B) and mean mass (C) of cherry tomato fruits cv. Samambaia in hydroponic cultivation as a function of nutrient ratios in the nutrient solution.

The titratable acidity of tomato fruits was altered by nutrient ratios in the nutrient solution $(50$, $75,100,125$ and $150 \%$ ), with values varying from 16.25 to $18.9 \%$. The highest average value estimated was $18.18 \%$ fruit $^{-1}$, corresponding to $116.6 \%$ of the standard nutrient solution, with subsequent decreases above this nutrient concentration level (Figure 2A). The results are lower than the variation obtained by Feltrin et al.
(2005) when evaluating the productivity and fruit quality of fertirrigated tomato cultivars with chloride and potassium sulphate in soil covered with black plastic mulch in a greenhouse, which verified that the means of titratable acidity did not suffer to the effects of mineral nutrition. However, there was a significant difference in titratable acidity between the cultivars, where the values ranged from $0.57 \%$ to $0.80 \%$. 
A

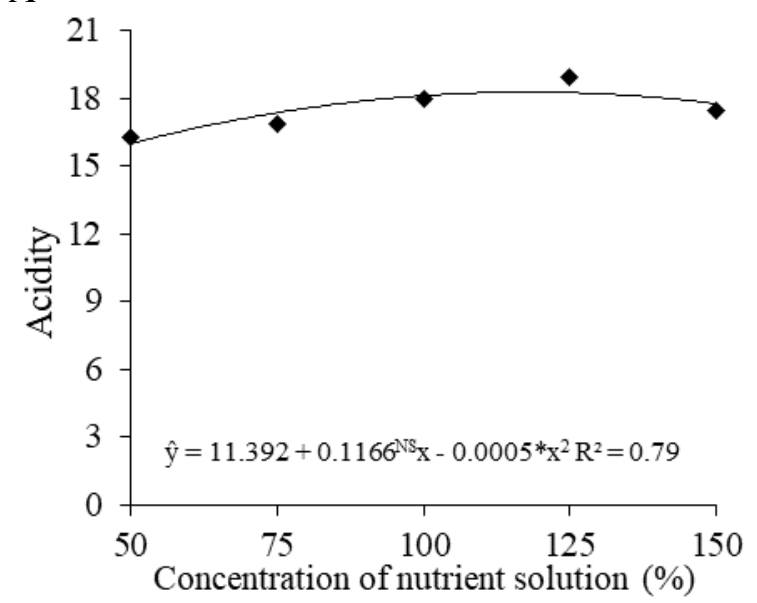

C

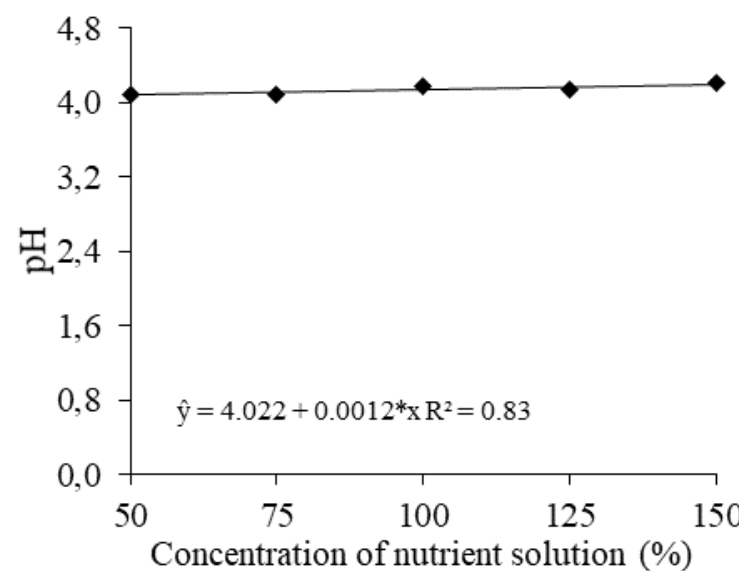

B

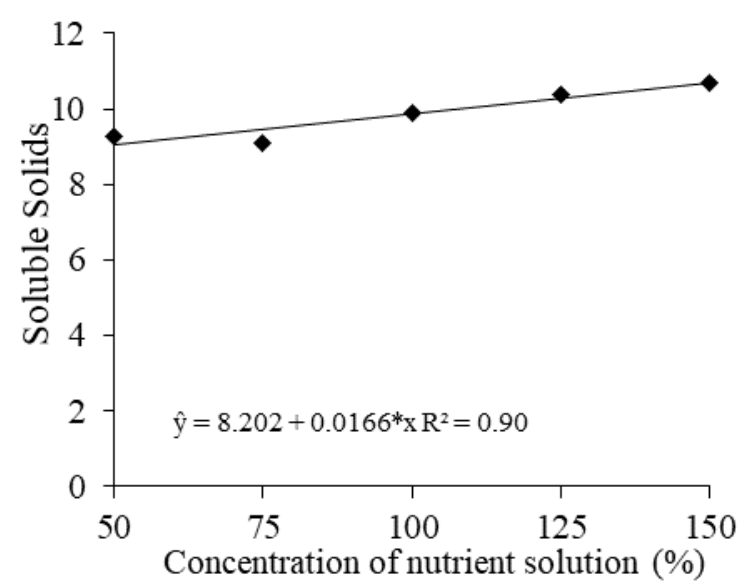

$\mathrm{D}$

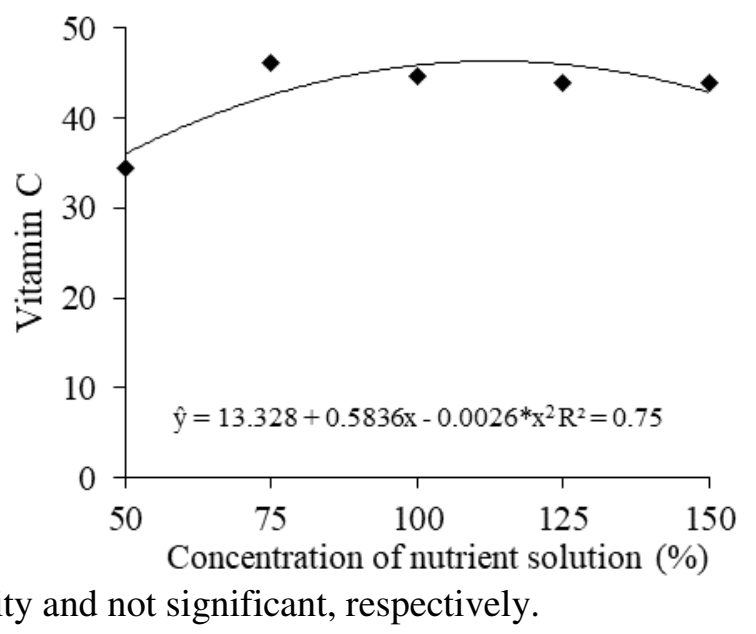

Figure 2. Acid titratable, \% citric acid (A), soluble solids, Brix (B), hydrogenation potential values, $\mathrm{pH}(\mathrm{C})$ and vitamin C, mg of ascorbic acid/100 g (D) of cherry tomato fruits cv. Samambaia in hydroponic cultivation as a function of nutrient ratios in the nutrient solution.

Soluble solids contents (Brix) increased linearly as a function of the nutrient concentration increase in the nutrient solution, registering 0.42 Brix for each $25 \%$ increase in solution concentration (Figure 2B). This can be explained by the excess salts in the nutrient solution due to the increase of nutrient concentrations $(1.8,2.0,2.6,3.4$ and $3.9 \mathrm{dS}$ $\mathrm{m}^{-1}$ ), which increased the ionic concentration in the interior of the plants and, consequently, the export of these ions to the fruits (ROCHA et al., 2010). The results obtained in the research were superior to those presented by Silva et al. (2012) on cherry tomatoes irrigated with high-salinity water $\left(4 \mathrm{dS} \mathrm{m}^{-}\right.$ $\left.{ }^{1}\right)$, which recorded linear increases in soluble solids content ( ${ }^{\circ}$ Brix) up to 7.98 .

The application of different nutrient ratios in the nutrient solution had a significant effect $(\mathrm{p}<$ 0.01 ) on the $\mathrm{pH}$ values of cherry tomato fruits (Figure 2D). The $\mathrm{pH}$ of the cherry tomato fruit pulp increased from 4.09 to 4.21 at nutrient ratios of 50 to $150 \%$, respectively (Figure $2 \mathrm{C}$ ). Fruit $\mathrm{pH}$ also increased as the salinity of the nutrient solution increased $\left(1.8,2.0,2.6,3.4\right.$ and $\left.3.9 \mathrm{dS} \mathrm{m}^{-1}\right)$. The results obtained for $\mathrm{pH}$ were similar to those observed by Feltrin et al. (2005) who evaluated the quality of fruits of fertirrigated tomato cultivars with chloride and potassium sulphate, and showed $\mathrm{pH}$ values from 3.96 to 4.17 .

As observed for the other characteristics of fruit quality, the increase of the nutrient ratios in the nutrient solution significantly influenced the vitamin C content of the cherry tomato fruits; it had a verified quadratic behavior with maximum vitamin $\mathrm{C}$ in the fruit of 46.07 ( $\mathrm{mg}$ of ascorbic acid/100 $\mathrm{g}$ of fruit) obtained in cultivated plants at the estimated concentration of $112.23 \%$ (Figure 3E). The levels of vitamin $\mathrm{C}$ observed in the present study exceed the range of 13.4 - 36.9 (mg of ascorbic acid/100 $\mathrm{g}$ of fruit) observed by Munhoz et al. (2011) and Silva et al. (2013b). This indicates that the cherry tomato has 
higher concentrations of vitamin $\mathrm{C}$ than the conventional tomato, which may be related to its reduced size.

\section{CONCLUSIONS}

The best production and post-harvest quality indexes of cherry tomatoes (cv. Samambaia) cultivated in a hydroponic system were found when using $111 \%$ of the standard nutrient solution, corresponding to the concentrations of $9.44,2.44$, $2.22,6.44,4.11,2.44$ and $2.78 \mathrm{mmol}_{\mathrm{c}} \mathrm{L}^{-1}$, of $\mathrm{NO}_{3}{ }^{-}$, $\mathrm{NH}_{4}{ }^{+}, \mathrm{P}, \mathrm{K}, \mathrm{Ca}, \mathrm{Mg}$ and $\mathrm{S}$, respectively, and 66.6, $55.5,14.4,1.89,0.56$ and $0.44 \mathrm{mmol}_{\mathrm{c}} \mathrm{L}^{-1}$, of Fe, B, $\mathrm{Mn}, \mathrm{Zn}, \mathrm{Cu}$ and $\mathrm{Mo}$, respectively.

Nutrient solutions with electrical conductivity above $2.89 \mathrm{dS} \mathrm{m} \mathrm{m}^{-1}$ promote reductions in the production of cherry tomatoes grown on coconut fiber substrates under protected conditions.

RESUMO: Devido à importância alimentar e industrial do tomateiro, a cultura destaca-se entre as hortaliças, sendo uma das espécies mais produzidas em sistema hidropônico de cultivo. Nosso objetivo foi avaliar os efeitos da aplicação de diferentes concentrações de solução nutritiva na produção e na qualidade dos frutos de tomate cereja (Licopersicon esculentum, cv. Samambaia) em sistema hidropônico sobre condição de ambiente protegido. O experimento foi conduzido em vasos preenchidos com substrato de fibra de coco utilizando o delineamento de blocos casualizados, com quatro repetições e seis plantas por parcela. Foram avaliadas cinco concentrações de nutrientes na solução nutritiva hidropônica (50, 75, 100, 125 e $150 \%$ da solução nutritiva padrão) que, após a diluição dos nutrientes em água de torneira, estas produziram as seguintes condutividades elétricas: $1.8,2.0,2.6,3.4$ e $3.9 \mathrm{dS} \mathrm{m} \mathrm{m}^{-1}$, respectivamente. Aos 90 dias após o transplantio, os frutos de tomate foram colhidos, ocasião em que se determinaram as variáveis de produção e qualidade póscolheita de frutos maduros. A análise dos resultados indicou que os melhores índices de produção e qualidade dos frutos de tomate cereja cultivado em sistema hidropônico foram encontrados nas concentrações de macronutrientes da solução nutritiva correspondente a 9,44;2,44;2,22;6,44; 4,11;2,44 e $2,78 \mathrm{mmol}_{\mathrm{c}} \mathrm{L}^{-1} \mathrm{de}_{\mathrm{e}}$ $\mathrm{NO}_{3}{ }^{-}, \mathrm{NH}_{4}{ }^{+}, \mathrm{P}, \mathrm{K}, \mathrm{Ca}, \mathrm{Mg}$ e S, respectivamente, e 66,6; 55,5; 14,4; 1,89; 0,56 e 0,44 mmol $\mathrm{L}^{-1}$, de Fe, B, Mn, $\mathrm{Zn}, \mathrm{Cu}$ e $\mathrm{Mo}$, respectivamente. As soluções nutritivas com condutividade elétricas acima de $2,89 \mathrm{dS} \mathrm{m}^{-1}$ reduziram severamente o rendimento de frutos de tomate cereja.

PALAVRAS-CHAVE: Licopersicon esculentum. Nutrientes. Irrigação. Hidroponia.

\section{REFERENCES}

ASSOCIATION OF OFFICIAL ANALYTICAL CHEMISTRY (AOAC). Official methods of analysis of the Association of Official Analytical Chemistry.17. ed. Washington: AOAC, 2002. 1115 p.

CARDOSO, D. S. C. P.; SEDIYAMA, M. A. N.; POLTRONIERI, Y.; FONSECA, M. C. M.; NEVES, Y. F. Effect of concentration and n:k ratio in nutrient solution for hydroponic production of cucumber. Revista Caatinga, Mossoró, v. 30, n. 4, p. 818-824, Ouc./Dec. 2017. http://dx.doi.org/10.1590/198321252017v30n401rc.

CARVALHO, L. A.; TESSARIOLI NETO, J. Produtividade de tomate em ambiente protegido, em função do espaçamento e número de ramos por planta. Horticultura Brasileira, Brasília, v. 23, n. 4 p. 986-989, Ouc./Dec. 2005. http://dx.doi.org/10.1590/S0102-05362005000400025.

COSME, C. R.; DIAS, N. S.; OLIVEIRA, A. M.; OLIVEIRA, E. M. M.; SOUSA NETO, O. N. Produção de tomate hidropônico utilizando rejeito da dessalinização na solução nutritiva aplicados em diferentes épocas. Revista Brasileira de Engenharia Agrícola e Ambiental, Campina Grande, v. 15, n. 5, p. 499-504, May. 2011. http://dx.doi.org/10.1590/S1415-43662011000500010.

DINIZ, A. A.; DIAS, N. S.; SOUZA, F. I.; SOUZA, A C. M.; MESQUITA, F. O.; SOUZA, F. I. Efeito da solução nutritiva sob o crescimento e composição mineral em pepino cultivado em substrato de fibra de coco. Semina: Ciências Agrárias, Londrina, v 36, n. 5, p. 3043-3053, Sep./Oct. 2015. http://dx.doi.org/10.5433/1679-0359.2015v36n5p3043. 
FELTRIN, D. M.; POTT, C. A.; FURLANI, P. R.; CARVALHO, C. R. L. Produtividade e qualidade de frutos de cultivares de tomateiro fertirrigado com cloreto e sulfato de potássio. Revista de Ciências Agroveterinárias, Lages, v. 4, n. 1, p. 17-24, Jan./Mar. 2005.

FERNANDES, A. A.; MARTINEZ, H. E. P.; OLIVEIRA, L. R. Produtividade, qualidade dos frutos e estado nutricional de plantas de pepino, cultivadas em hidroponia, em função das fontes de nutrientes. Horticultura Brasileira, Brasília, v. 20, n. 4, p. 571-575, Oct./Dec. 2002. http://dx.doi.org/10.1590/S010205362002000400011.

FERREIRA, D. F. Sisvar: a Guide for its Bootstrap procedures in multiple comparisons. Ciência e Agrotecnologia, Lavras, v. 38, n. 2, p. 109-112, Mar./Apr. 2014. http://dx.doi.org/10.1590/S141370542014000200001.

FURLANI, P. R.; BOLONHEZI, D.; SILVEIRA, L. C. P.; FAQUIN, V. Nutrição mineral de hortaliças, preparo e manejo de soluções nutritivas. Informe Agropecuário, Belo Horizonte, v. 20, n. 200/201, p. 90-98, 1999.

GENÚNCIO, G. C.; MAJEROWICZ, N.; ZONTA, E.; SANTOS, A. M.; GRACIA, D.; AHMED, C. R. M.; SILVA, M. G. Crescimento e produtividade do tomateiro em cultivo hidropônico NFT em fungos da concentração iônica da solução nutritiva. Horticultura Brasileira, Brasília, v. 24, n. 2, p. 175-179, Apr./Jun. 2006. http://dx.doi.org/10.1590/S0102-05362006000200010.

GUILHERME, D. O.; PINHO, L.; CAVALCANTI, T. F. M.; COSTA, C. A.; ALMEIDA, A. C.; Análise sensorial e físico-química em frutos de tomate cereja orgânicos. Revista Caatinga, Mossoró, v.27, n. 1, p.181186, Jan./Mar. 2014.

IAL - INSTITUTO ADOLFO LUTZ. Métodos físico-químicos para análise de alimentos. 4. ed. São Paulo: IAL, 2008. 1018p.

MEDEIROS, R. F.; CAVALCANTE, L. F.; MESQUITA, F. O.; RODRIGUES, R. M.; SOUSA, G. G.; DINIZ, A. A. Crescimento inicial do tomateiro-cereja sob irrigação com águas salinas em solo com biofertilizantes bovino. Revista Brasileira de Engenharia Agrícola e Ambiental, Campina Grande, v. 15, n. 5, p. 505-511, May. 2011. http://dx.doi.org/10.1590/S1415-43662011000500011.

MELO, N. C.; SOUZA, L. C.; SILVA, V. F. A.; GOMES, R. F.; OLIVEIRA NETO, C. F.; COSTA, D. L. P. Cultivo de tomate (Solanum lycopersicum) hidropônico sob diferentes níveis de fósforo e potássio em solução nutritiva. Agroecossistemas, Belém, v. 6, n. 1, p. 10-16, Jan./Mar. 2014.

http://dx.doi.org/10.18542/ragros.v6i1.1845.

MUNHOZ, C. L.; BRANCO, I. G.; SANJINEZ-ARGANDOÑA, E. J. Caracterização e aceitabilidade de tomate seco characterization and acceptance of dried tomato. Revista Brasileira de Tecnologia Agroindustrial, Ponta Grossa, v. 5, n. 1, p. 252-262, Jan./Mar. 2011. http://dx.doi.org/10.3895/S198136862011000100001.

OLIVEIRA, F. A.; OLIVEIRA, M. K. T.; MEDEIROS, J. F.; PRAZERES, O. M.; PAIVA, E. P.; MAIA, P. M. E. Produtividade do maxixeiro cultivado em substrato e fertirrigado com soluções nutritivas. Horticultura Brasileira, Brasília, v. 32, n. 4, p. 464-467, Ouc./Dec. 2014. http://dx.doi.org/10.1590/S0102053620140000400015.

OLIVEIRA, F. A.; SÁ, F. V. S.; PEREIRA, F. H. F.; ARAUJO, F. N.; PAIVA, E. P.; ALMEIDA, J. P. N. Comportamento fisiológico e crescimento de plantas de melancieira sob diferentes concentrações de solução nutritiva. Revista Brasileira de Agricultura Irrigada, Fortaleza, v. 10, n. 3, p. 439-448, May./Jun. 2016. http://dx.doi.org/10.7127/RBAI.V10N100365. 
RINALDI, M. M.; SANDRI, D.; RIBEIRO, M. O.; AMARAL, A. G. Características físico-químicas e nutricionais de pimentão produzido em campo e hidroponia. Ciência Tecnologia Alimentar, Campinas, v. 28, n. 3, p. 558-563, Jul./Sep. 2008. http://dx.doi.org/10.1590/S0101-20612008000300009.

ROCHA, M. Q.; PEIL, R. M. N.; COGO, C. M. Rendimento do tomate cereja em função do cacho floral e da concentração de nutrientes em hidroponia. Horticultura Brasileira, Brasília, v. 28, n. 4, p. 466-471, Ouc./Dec. 2010. http://dx.doi.org/10.1590/S0102-05362010000400015.

SÁ, F. V. S.; BRITO, M. E. B.; SILVA, L. A.; MOREIRA, R. C. L.; FERNANDES, P. D.; FIGUEIREDO, L. C. Fisiologia da percepção do estresse salino em híbridos de tangerineira-Sunki Comum sob solução hidropônica salinizada. Comunicata Scientiae, Bom Jesus, v. 6, n. 4, p. 463-470, Oct./Dec. 2015. https://doi.org/10.14295/cs.v6i4.1121.

SANTOS, A. N.; SILVA, E. F. F.; SILVA, G. F.; BEZERRA, R. R.; PEDROSA, E. M. R. Concentração de nutrientes em tomate cereja sob manejos de aplicação da solução nutritiva com água salobra. Revista Ciência Agronômica, Fortaleza, v. 48, n. 4, p. 576-585, Oct./Dec. 2017. http://dx.doi.org/10.5935/18066690.20170067.

SILVA, E. C.; ALVARENGA, P. P. M.; MACIEL, G. M. Avaliações físico-quimicas de frutos de tomateiro em função de doses de potássio e nitrogênio. Bioscience Journal, Uberlândia, v. 29, n. 6, p. 1788-1795, Nov./Dec. 2013b.

SILVA, F. V.; DUARTE, S. N.; LIMA, C. J. G. DE S.; DIAS, N. S.; SANTOS, R. S. S.; Medeiros, P. R. F. Cultivo hidropônico de rúcula utilizando solução nutritiva salina. Revista Brasileira de Ciências Agrárias, Recife, v. 8, n. 3, p. 476-482, Jul./Sep. 2013a. http://dx.doi.org/10.5039/agraria.v8i3a1689.

SILVA, P. F.; SILVA, A. C. C.; TAVARES, K. N.; SANTOS, D. P.; BARROS, A. C. Produção e teor de brix do tomate cereja irrigado com águas de diferentes concentrações salina. Revista Verde de Agroecologia e Desenvolvimento Sustentável, Pombal, v. 7, n. 4, p. 85-89, Oct./Dec. 2012.

STRASSBURGER, A. S.; PEIL, R. M. N.; FONSECA, L. A.; AUMONDE, T. Z. Crescimento e produtividade da abobrinha italiana: efeito da concentração iônica da solução nutritiva. Semina: Ciências Agrárias,

Londrina, v 32, n. 2, p. 553-564, Apr./Jun. 2011. http://dx.doi.org/10.5433/1679-0359.2011v32n2p553. 